\title{
Multiple embolic stroke due to aortic arch floating thrombus in latent tertiary syphilis
}

\author{
Paolo Ripellino, ${ }^{1}$ Daniela Mittino, ${ }^{1}$ Pamela Farinelli, ${ }^{2}$ Roberto Cantello ${ }^{1}$
}

'Department of Neurology, University of Eastern Piedmont, AOU Maggiore della Carità, Novara, Italy

${ }^{2}$ Department of Dermatology, University of Eastern Piedmont AOU Maggiore della Carità, Novara, Italy

\section{Correspondence to} Dr Paolo Ripellino,

pao.ripe@hotmail.it

CrossMark

o cite: Ripellino $P$ Mittino D, Farinelli $P$, et al. BMJ Case Rep Published online: [please include Day Month Year] doi:10.1136/ bcr-2013-200910

\section{DESCRIPTION}

A 57-year-old man was hospitalised in the emergency ward because of sudden appearance of nausea, vomiting, dizziness, nystagmus, motor aphasia associated to pain and cyanosis in the left arm. Doppler sonography detected a left omeral artery occlusion, due to acute embolism. The first brain CT scan was negative, but $24 \mathrm{~h}$ later
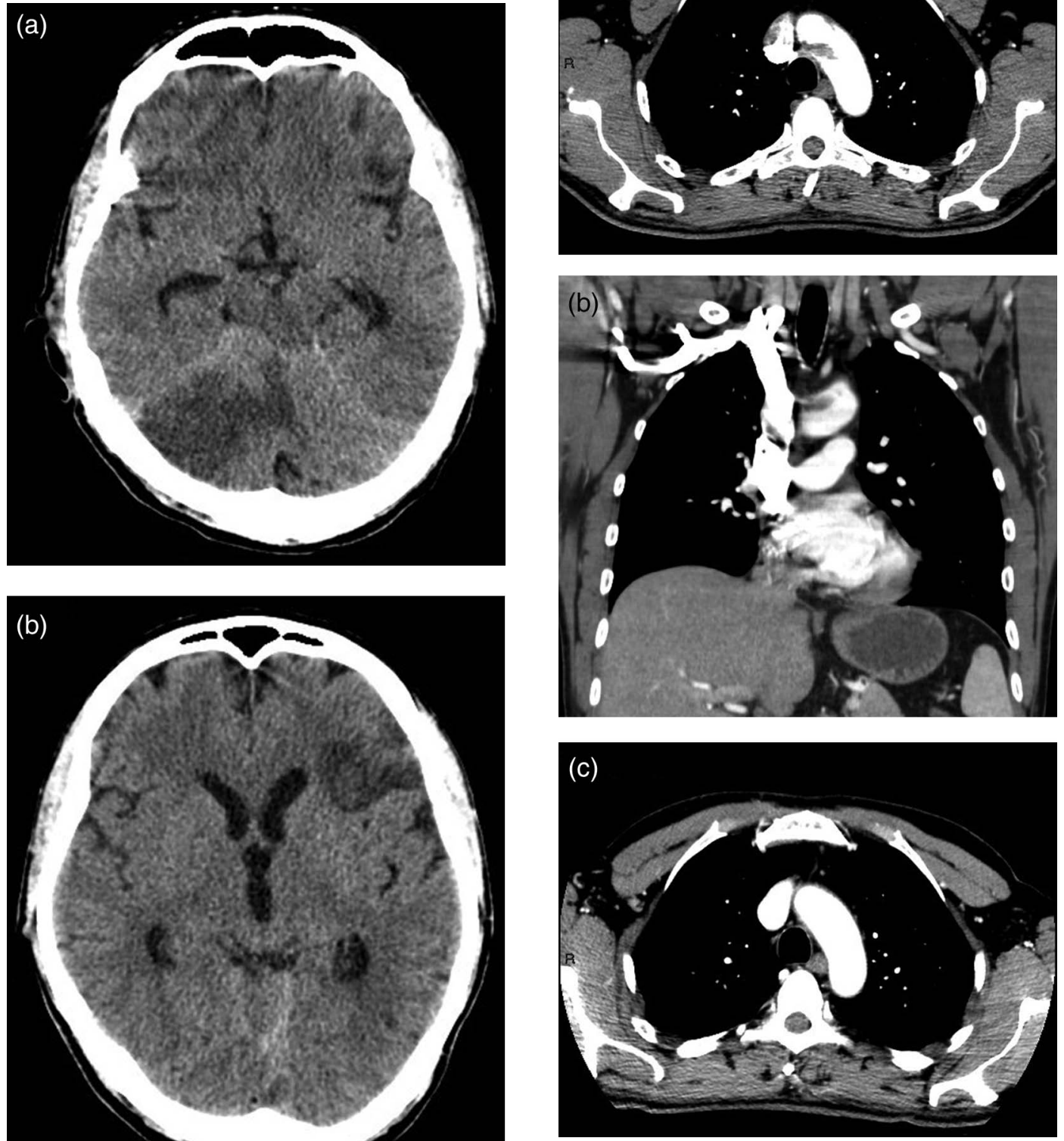

Figure 2 Floating thrombus. CT angiography at admittance: axial CT scan (A) and coronal reconstruction (B) showing an ulcerated plaque in the aortic arch, complicated by acute massive thrombosis $(18 \times 11 \mathrm{~mm})$. At control (C): after 25 days of anticoagulation the thrombus totally disappeared.

evidenced multiple ischaemic infarctions in the brain (right cerebellar hemisphere, Broca's area; figure 1).

Disseminated arterial multiple embolisms (involving in this case the brain and an upper limb)
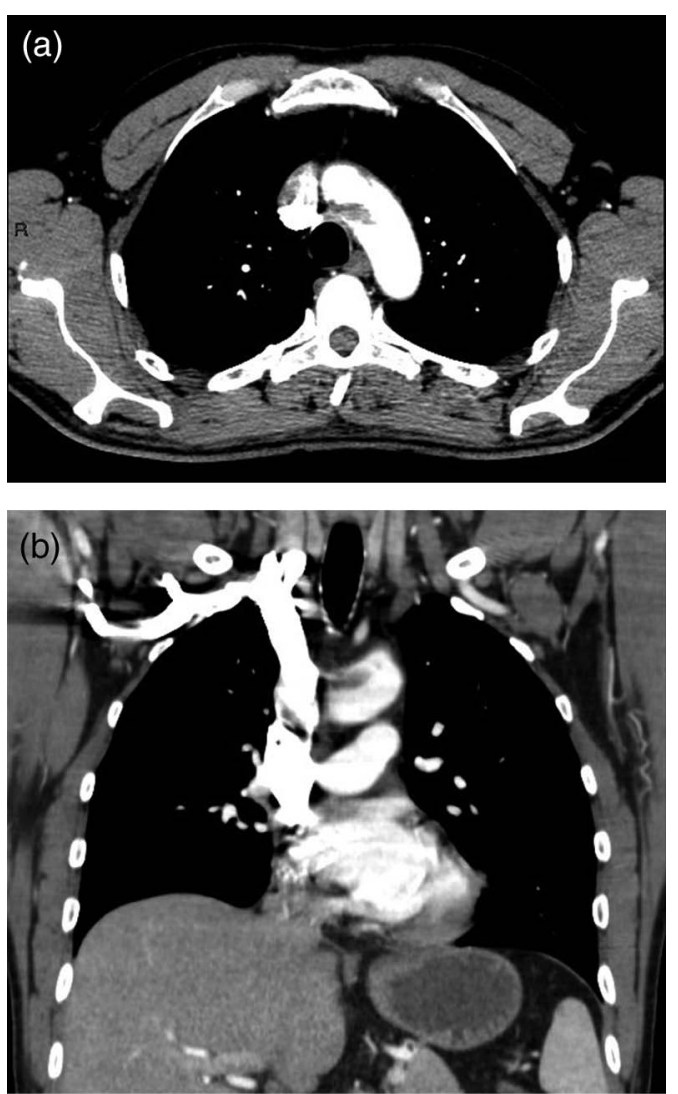

Figure 1 Embolic stroke. Brain CT scan after $24 \mathrm{~h}$ from admittance showing multiple ischemic areas in the cerebellum (vermis and right hemisphere; $A$ ) and in the pars opercularis of the inferior frontal gyrus (B). 
usually originate from fragments of cardiac or aortic thrombus. The CT angiography in the acute phase detected a floating thrombus in the ascending aortic arch and no concomitant lesions in the aortic wall or in the cerebral arterial vessels. There was no sign of isolated central nervous system vasculitis. The only cardiovascular factor detectable was hyperhomocysteinaemia; the entire autoimmunity panel (and especially antiphospholid antibodies) was negative.

Looking for causes of isolated ascending aortitis ${ }^{1,2}$ (related to congenital collagenopathies, to infectious or autoimmune diseases), we diagnosed a latent tertiary syphilis ${ }^{3}$. At admittance serological tests (RPR 1:25, TPPA 1:10240, IgM anti-Treponema Pallidum negative, total antibodies against Treponema pallidum $>70.00$ ), the absence of history and the absence of previous treatment with penicillin led to the diagnosis of latent syphilis. Concomitant viral infections (HIV, HBV and HCV) were excluded with adequate serological test. Lumbar puncture was not performed because of the urgent need for anticoaugulation. Despite the lack of histological confirmation (the patient did not undergo cardiothoracic surgery because of the favourable outcome) we concluded that the explanation was luetic aortic damage, ${ }^{4}$ which could have promoted the thrombus growth with consequent multiple symptomatic embolisms.

The patient was anticoagulated with continuous heparin infusion for several days followed by oral sodic warfarin (international normalised ratio (INR) 2.5-3) and treated with intravenous penicillin at the dose of $1 \mathrm{~g}$ every $6 \mathrm{~h}$ for 10 days. After 25 days, the floating thrombus completely disappeared (figure 2) and most of the neurological symptoms dramatically improved. After an 8-month follow-up, the patient's condition was stable and serological luetic antibodies decreased in accordance with the treatment (immunological scar).

\section{Learning points}

- Syphilis in developed countries is a re-emerging disease that can mimic many medical conditions and can be the underlying cause of serious cardiovascular disorders.

- A floating thrombus in the aortic arch is an emergency that should be operated or anticoagulated immediately because of the high risk of sudden multiple embolisms.

Acknowledgements The authors would like to thank Dr Lorenzo Coppo for his help in the clinical management of the patient and in the diagnostic procedure.

Contributors PR contributed in the conception and design, acquisition of data, analysis and interpretation of data; drafting the article; final approval of the version published. DM was responsible for the acquisition of the data, analysis and interpretation of the data; final approval of the version published. PF was responsible for the analysis and interpretation of data; drafting the article; final approval of the version published. RC was responsible for the revision of the paper for important intellectual content; final approval of the version published.

Competing interests None.

Patient consent Obtained.

Provenance and peer review Not commissioned; externally peer reviewed.

\section{REFERENCES}

1 Tavora F, Burke A. Review of isolated ascending aortitis: differential diagnosis, including syphilitic, Takayasu's and giant cell aortitis. Pathology 2006;38:302-8.

2 Katabathina VS, Restrepo CS. Infectious and noninfectious aortitis: cross-sectional imaging findings. Semin Ultrasound CT MR 2012;33:207-21.

3 Roberts WC, Ko JM, Vowels TJ. Natural history of syphilitic aortitis. Am J Cardiol 2009; 104:1578-87.

4 Heggtveit HA. Syphilitic aortitis. A clinicopathologic autopsy study of 100 cases, 1950-1960. Circulation 1964;29:346-55.

Copyright 2013 BMJ Publishing Group. All rights reserved. For permission to reuse any of this content visit http://group.bmj.com/group/rights-licensing/permissions.

BMJ Case Report Fellows may re-use this article for personal use and teaching without any further permission.

Become a Fellow of BMJ Case Reports today and you can:

- Submit as many cases as you like

- Enjoy fast sympathetic peer review and rapid publication of accepted articles

- Access all the published articles

- Re-use any of the published material for personal use and teaching without further permission

For information on Institutional Fellowships contact consortiasales@bmjgroup.com

Visit casereports.bmj.com for more articles like this and to become a Fellow 